\title{
Pengaruh Beban Kerja, Stres Kerja, dan Motivasi terhadap Kinerja Karyawan RS Ludira Husada Tama Yogyakarta
}

\author{
Gabriela Kartika Y.S.A, Sri Haryani ${ }^{凶}$ \\ Sekolah Tinggi Ilmu Manajemen YKPN Yogyakarta \\ e-mail: sriharyani@stimykpn.ac.id
}

\begin{abstract}
Organizations or companies need human resources to carry out all business activities, both related to operations, marketing, finance, human resources, and information systems. Human resources are believed to be one of the key factors in achieving superior organizational performance. Of the various factors that must be considered to achieve this performance are workload, work stress, and motivation. This study aims to analyze the effect of work load, work stress, and motivation on RS Ludira Husada Tama employee's performance.The number of samples was 110 respondents, data collection using questionnaires, and using linear regression analysis. The results in this study indicate: workload and motivation variables partially affect employee performance; workload, work stress, and motivation variables simultaneously influence employee performance; of the three variables; the biggest influence on employee's performance is the workload variable. Overall, workload, work stress, and motivation variables contributed to the influence of $26.4 \%$ while the remaining $73.6 \%$ was influenced by other variables not included in the research model.
\end{abstract}

Keywords: workload, workstress, motivation, employee performance

\begin{abstract}
Abstrak
Organisasi/perusahan memerlukan sumber daya manusia untuk menjalankan seluruh aktivitas usahanya, baik yang berhubungan dengan operasi, pemasaran, keuangan, sumberdaya manusia, maupun sistem informasinya. Sumber daya manusia diyakini menjadi salah satu faktor penting dalam mencapai kinerja organisasi yang unggul. Dari berbagai faktor yang harus diperhatikan untuk mencapai kinerja tersebut adalah beban kerja, stres kerja, dan motivasi. Penelitian ini bertujuan untuk menganalisis pengaruh beban kerja, stres kerja, dan motivasi terhadap kinerja karyawan Rumah Sakit Ludira Husada Tama Yogyakarta. Jumlah sampel sebesar 110 responden, pengumpulan data menggunakan kuesioner, dan menggunakan analisis regresi linear. Hasil dalam penelitian menunjukkan: variabel beban kerja dan motivasi secara parsial berpengaruh terhadap kinerja karyawan; variabel beban kerja, stres kerja, dan motivasi secara simultan berpengaruh terhadap kinerja karyawan; dari ketiga variabel, yang paling besar pengaruhnya adalah variabel beban kerja. Variabel beban kerja, stres kerja, dan motivasi memberikan sumbangan pengaruh sebesar $26,4 \%$ sisanya sebesar 73,6\% dipengaruhi oleh variabel lain yang tidak dimasukkan dalam model penelitian.
\end{abstract}

Kata kunci: beban kerja, stres kerja, motivasi, kinerja karyawan. 


\section{PENDAHULUAN}

Manajemen sumber daya manusia (MSDM) merupakan salah satu bidang manajemen yang berperan penting untuk mencapai tujuan organisasi/perusahaan. Organisasi/perusahaan memerlukan sumber daya manusia untuk mengelola seluruh aktivitasnya, baik yang berhubungan dengan produksi, pemasaran, keuangan, umum, dan sistem yang digunakan. Dalam proses pencapaian tujuan, organisasi/perusahaan memberikan standar yang harus dicapai oleh setiap karyawan. Untuk mengoptimalkan hasil kerja karyawan dalam melaksanakan tugas dan tanggung jawabnya dapat dilakukan dengan cara menilai prestasi kerja karyawan.

Kriteria penilaian meliputi tanggung jawab, ketaatan, kejujuran, dan kerjasama dalam tim. Kinerja karyawan antara lain dipengaruhi oleh faktor pengalaman, ketrampilan, kemampuan, pendidikan, beban kerja, stress kerja, motivasi, K3 dan lainlain. Penilaian kinerja dapat dilakukan oleh atasan langsung dan teman sejawat, atau oleh seseorang tertentu yang menurut pemimpin memiliki keahlian dalam bidangnya. Penilaian kinerja secara formal dilakukan secara periodik, seperti setiap bulan, triwulan, kwartal, semester, atau setiap tahun. Penilaian kinerja secara informal dilakukan secara terus menerus dan setiap saat atau setiap hari kerja, Mangkunegara (2013). Penilaian prestasi kerja dilakukan untuk meningkatkan kapasitas yang dimiliki karyawan untuk memanfaatkan peluang yang ada, untuk menghindari berbagai ancaman, dan untuk meminimalisir berbagai kelemahan yang dimiliki karyawan. Meskipun demikian, penilaian prestasi kerja sering kali menimbulkan tekanan dan beban bagi karyawan. Hal ini disebabkan karyawan khawatir penilaian prestasi kerjanya tidak baik atau tidak mencapai standar yang telah ditetapkan.

Beban kerja merupakan sejumlah target pekerjaan atau target hasil yang harus dicapai dalam satu satuan waktu tertentu (Kepmenpan No 75 Thn 2004). Menurut Munandar (2014) beban kerja merupakan tugas-tugas yang diberikan karyawan untuk diselesaikan pada waktu tertentu menggunakan keterampilan dan potensi dari tenaga kerja. Beban kerja dapat dibedakan ke dalam beban kerja kuantitatif yang timbul sebagai akibat dari tugas-tugas yang terlalu banyak atau terlalu sedikit yang diberikan kepada karyawan untuk diselesaikan dalam waktu tertentu. Beban kerja kualitatif dimana karyawan merasa tidak mampu untuk melakukan suatu tugas atau tugas tidak menggunakan keterampilan dan/atau potensi dari karyawan. Mengatur beban kerja bagi setiap karyawan sangatlah penting agar karyawan tidak mengalami tekanan dan stres.

Beban kerja yang ditanggung oleh karyawan yang bekerja di rumah sakit akan berbeda dengan karyawan yang bekerja diluar rumah sakit. Secara umum, melayani orang yang sehat akan berbeda dengan melayani orang yang sakit. Dengan menggunakan analisis beban kerja yang dikembangkan Tarwaka dkk. (2004) beban kerja di rumah sakit berkaitan dengan tugsanya melakukan pelayanan dan perawatan untuk orang yang sakit. Kedua, bekerja di rumah sakit dengan sistem kerja shift, menuntut kesiapan fisik untuk bekerja pada shift malam yang merupakan waktu istirahat. Lingkungan kerja rumah sakit akan berbeda dengan lingkungan kerja sektor perbankan, perdagangan, pendidikan, maupun pariwisata. Bekerja di rumah sakit, khususnya divisi medis, menuntut ketrampilan khusus yang apabila tidak diperhatikan dapat berakibat fatal bagi nyawa manusia. Terakhir, adanya tuntuan perilaku karyawan yang harus dijaga, di mana orang sakit beserta keluarganya perlu mendapatan empati dari rumah sakit beserta seluruh karyawannya.

Menurut Wijono (2012) stres kerja merupakan suatu kondisi dari hasil penghayatan subjektif individu yang 
dapat berupa interaksi antara individudan lingkungan kerja yang dapat mengancam dan memberi tekanan secara psikologis, fisiologis dan sikap individu. Stres dapat terjadi karena beberapa faktor, antara lain dari faktor pekerjaan, faktor non-pekerjaan, dan faktor dari pribadi seseorang. Stres dapat berakibat positif dan negatif. Akibat positif dari stres seperti dapat memotivasi seseorang, merangsang kreativitas, mendorong untuk lebih giat bekerja, dan memberikan inspirasi untuk menjalani hidup yang lebih baik. Akibat negatif dari stres yaitu individu akan merasa cemas, agresif, depresi, emosi meningkat, gugup, dan mengasingkan diri. Stres dapat dihindari oleh setiap karyawan. Oleh sebab itu pemimpin bertanggung jawab terhadap keamanan, kenyamanan dari setiap tugas yang diberikan kepada karyawannya.

Terdapat berbagai faktor yang menyebabkan karyawan stres dan faktor penyebab stres antara karyawan satu bisa jadi berbeda dengan karyawan lain. Hasibuan (2016) menyebutkan adanya beberapa faktor penyebab stres, pertama beban kerja. Karyawan yang bekerja di rumah sakit aka menanggung beban kerja seperti diuraikan di atas, yang dapat menyebabkan stres. Adanya tekanan dari pemimpin untuk bekerja sesuai dengan standar yang telah ditetapkan. Selain itu sikap pimpinan yang kurang adil juga dapat menjadi penyebab stres. Peralatan kerja yang kurang memadai yang menyebabkan hasil kerja tidak optimal juga menyebabkan stres. Konflik antar karyawan atau konflik dengan atasan dapat menjadi penyebab stres, karena lingkungan kerja menjadi tidak nyaman, bahkan dapat tidak kondusif untuk bekerja.

Motivasi adalah suatu proses dimana kebutuhan-kebutuhan mendorong seseorang untuk melakukan serangkaian kegiatan yang mengarah ke tercapainya tujuan tertentu (Munandar, 2014). Pemberian motivasi merupakan sebuah metode bagaimana karyawan dapat ditangani secara tepat untuk mencapai tujuan yang telah ditetapkan. Motivasi diyakini oleh pimpinan/manajer dapat meningkatkan kinerja karyawan pada berbagai sektor. Penelitian Adriansyah (2017) dan Aprilia (2017) yang meneliti pengaruh motivasi pada karyawan rumah sakit, dan penelitian Darmawan (2017) serta Latifah dan Haryani (2014) pada sektor non rumah sakit menunjukkan adanya pengaruh motivasi terhadap kinerja. Pimpinan/manajer perlu memahami secara tepat, motivasi apa yang sesuai untuk diberikan kepada karyawannya. Motivasi yang tepat akan meningkatkan kinerja karyawan.

\section{Beban Kerja}

Beban kerja dapat didefinisikan sebagai sejumlah target pekerjaan atau target hasil yang harus dicapai dalam satu satuan waktu tertentu (Kepmenpan No 75 Thn 2004). Menurut Pemendagri No 12 tahun 2008 beban kerja didefinisikan sebagai besaran pekerjaan yang harus dipikul oleh suatu jabatan atau unit organisasi dan merupakan hasil kali antara volume kerja dan norma waktu. Perka BKN No 19 Thn 2011 tentang pedoman umum penyusunan kebutuhan PNS, menjelaskan bahwa beban kerja merupakan faktor penting dalam menghitung kebutuhan pegawai. Beban kerja ditetapkan berdasarkan tugas dan fungsional unit organisasi yang selanjutnya diuraikan menjadi rincian tugas yang disesuaikan pada jangka waktu tertentu. Menurut Munandar (2014) beban kerja merupakan tugas-tugas yang diberikan karyawan untuk diselesaikan pada waktu tertentu menggunakan keterampilan dan potensi dari tenaga kerja.Tarwaka dkk.(2004) menyebutkan beban kerja merupakan suatu yang muncul dari interaksi antara tuntutan tugas, waktu, lingkungan kerja, tempat kerja, keterampilan, perilaku dan persepsi dari pekerjaan. Menurut PPM (1994) beban kerja adalah sejumlah kerja yang direncanakan atau yang sedang dikerjakan oleh karyawan perorangan, departemen, atau organisasi, biasanya dinyatakan dalam unit kerja. 
Menurut Tarwaka dkk. (2004) hubungan antara beban kerja dan kapasitas kerja dipengaruhi oleh berbagai faktor yang sangat kompleks, baik faktor internal maupun faktor eksternal. Beban kerja karena faktor eksternal adalah beban kerja yang berasal dari luar tubuh pekerja. Beban kerja eksternal antara lain meliputi: tugastugas (tasks), organisasi kerja yang dapat mempengaruhi beban kerja seperti lamanya bekerja, waktu kerja, waktu istirahat, kerja bergilir, kerja malam, sistem pengupahan, sistem kerja, musik kerja, model struktur organisasi, pelimpahan tugas, wewenang, dan lingkungan kerja. Beban kerja karena faktor internal adalah faktor yang berasal dari dalam tubuh itu sendiri sebagai akibat adanya reaksi dari beban kerja eksternal (strain). Faktor internal tersebut antara lain : faktor somatis (jenis kelamin, umur, ukuran tubuh, kondisi kesehatan, status gizi), dan faktor psikis (motivasi, persepsi, kepercayaan, keinginan, kepuasan, dan lain-lain).

Penelitian tentang beban kerja di rumah sakit ini sudah diteliti oleh beberapa peneliti, seperti Aprilia dkk. (2017) yang meneliti Pengaruh Beban Kerja, Stres Kerja Dan Motivasi Kerja Terhadap Kinerja Perawat Rumah Sakit Islam Ibnu Sina Pekanbaru. Hasil penelitiannyamenyimpulkan bahwa beban kerja berpengaruh terhadap kinerja karyawan, sedang hubungan antara beban kerja dan kinerja karyawan adalah negatif. Andriansyah (2017) yang meneliti Pengaruh Beban Kerja, Stress Kerja dan Motivasi terhadap Kinerja Perawat Pada Rumah Sakit Jiwa Amino Gondohutomo Provinsi Jawa Tengah menyimpulkan bahwa beban kerja memiliki pengaruh secara negatif terhadap kinerja karyawan. Penelitian Astianto (2014) juga menyimpulkan bahwa beban kerja berpengauhterhadap kinerja karyawan PDAM Surabaya. Berdasar landasan teori dan penelitian terdahulu, maka disusun hipotesis:
H1: Beban kerja secara parsial berpengaruh negatif terhadap kinerja karyawan RS Ludiro Husada Tama Yogyakarta.

\section{Stres Kerja}

Menurut Hasibuan (2016) stres kerja merupakan suatu kondisi ketegangan yang mempengaruhi emosi, proses berpikir, dan kondisi seseorang. Orang-orang yang mengalami stres menjadi nervous dan merasakan kekuatiran kronis. Mereka sering menjadi marah-marah, agresif, tidak dapat relaks, atau memerlihatkan sikap yang tidak kooperatif. Pada umumnya para ahli membahas stres dari dua aspek yaitu tentang pemicunya dan tentang respon yang timbul akibat stres. Salah satu pemicu stres yaitu situasi atau peristiwa yang bersifat fisik, emosional, seperti kecelakaan mobil, perdebatan di kantor, kehilangan pekerjaan, atau kehilangan orang yang dikasihi. Stres juga bisa timbul akibat respon fisik dan psikis individu terhadap peristiwa tertentu, seperti ancaman yang dirasakan karena tidak mendapatkan promosi di kantor.

Penyebab stres menunjukkan situasi dan peristiwa yang menciptakan sebuah respon, sedang stres adalah reaksi tubuh terhadap penyebab tersebut (Losyk, 2007). Stres juga bisa timbul akibat tuntutan-tuntutan individu terhadap dirinya sendiri, misalnya berusaha menjadi seorang perfeksionis. Tidak seorangpun di dunia ini yang sempurna, sehingga seseorang perlu terus menerus mengulangi atau memperbaiki tugas tertentu agar sempurna dalam pengerjaan suatu tugas atau kegiatan. Stres menimbulkan lebih banyak tuntutan terhadap tubuh, baik fisik maupun mental.

Hasibuan (2016) menyebutkan secara rinci adanya 6 faktor penyebab stres yaitu: a) beban kerja yang sulit dan berlebihan; b) tekanan dan sikap pimpinan yang kurang adil dan wajar; c) waktu dan peralatan kerja yang kurang memadai; d) konflik antara pribadi dengan pimpinan atau kelompok 
kerja; e) balas jasa yang terlalu rendah; dan f) masalah-masalah keluarga seperti anak, istri, mertua dan lain-lain.

Safaria dan Saputra (2009) menyebutkan bahwa stres dapat menimbulkan dampak negatif bagi individu. Dampak tersebut bisa merupakan gejala fisik maupun psikis dan akan menimbulkan gejala-gejala tertentu. Reaksi dari stres bagi individu dapat digolongkan menjadi beberapa gejala, pertama gejala fisiologis, berupa keluhan seperti sakit kepala, sembelit, diare, sakit pinggang, urat tegang pada tengkuk, tekanan darah tinggi, kelelahan, sakit perut, maag, berubah selera makan, susah tidur, dan kehilangan semangat. Kedua, gejala emosional, berupa keluhan seperti gelisah, cemas, mudah marah, gugup, takut, mudah tersinggung, sedih dan depresi.Ketiga, gejala kognitif, berupa keluhan seperti susah berkonsentrasi, sulit membuat keputusan, mudah lupa, melamun secara berlebihan, dan pikiran kacau. Keempat, gejala Interpersonal, berupa sikap acuh tak acuh pada lingkungan, apatis, agresif, minder, kehilangan kepercayaan pada orang lain, dan mudah mempersalahkan orang lain. Terakhir, gejala organisasional, berupa meningkatnya keabsenan dalam kerja atau kuliah, menurunnya produktivitas, ketegangan dengan rekan kerja, ketidakpuasan kerja dan menurunnya dorongan untuk berprestasi.

Hasil penelitian Aprilia dkk. (2017) menunjukkan bahwa stres kerja berpengaruh terhadap kinerja karyawan di RS Islam Ibnu Sina Pekanbaru. Pengaruh stress kerja terhadap kinerja karyawan bersifat negatif. Andriansyah (2017), juga menyimpulkan bahwa stres kerja berpengaruh terhadap kinerja Perawat Pada Rumah Sakit Jiwa Amino Gondohutomo Provinsi Jawa Tengah. Berdasar landasan teori dan penelitian terdahulu, maka disusun hipotesis kedua:

$\mathrm{H} 2$ : Stres kerja secara parsial berpengaruh negatif terhadap kinerja karyawan RS Ludiro Husada Tama Yogyakarta.

\section{Motivasi}

Hanafi (2011) mengatakan motivasi merupakan sesuatu yang mendorong seseorang bertindak atau berperilaku tertentu. Menurut pendapat Triatna (2015) motivasi merupakan suatu proses yang dilandasi oleh suatu dorongan. Dorongan inilah yang kemudian disebut sebagai kebutuhan. Karena adanya suatu dorongan tersebut, Munandar (2014) menjelaskan bahwa motivasi merupakan suatu proses dimana kebutuhan-kebutuhan mendorong seseorang untuk melakukan serangkaian kegiatan yang mengarah ke tercapainya tujuan tertentu. Sedarmayanti (2016) juga menjelaskan bahwa motivasi merupakan kesediaan mengeluarkan tingkat upaya tinggi ke arah tujuan organisasi yang dikondisikan oleh kemampuan upaya untuk memenuhi kebutuhan hidup.

Salah satu teori motivasi yang banyak diaplikasikan dalam penelitian adalah teori tingkat kebutuhan yang dikembangkan oleh Abraham Maslow (Hanafi, 2011). Maslow menjelaskan bahwa hirarki lima kebutuhan secara berurutan, pertama kebutuhan fisiologis, antara lain: rasa lapar, haus, perlindungan (pakaian dan perumahan), seks, dan kebutuhan lain. Kedua, kebutuhan keamanan, antara lain: keselamatan dan perlindungan terhadap kerugian fisik dan emosional. Ketiga, kebutuhan sosial, mencakup: cinta kasih, rasa memiliki (belonging), memberi dan menerima persahabatan. Keempat, penghargaan, mencakup faktor rasa hormat internal seperti: harga diri, otonomi dan prestasi dan faktor hormat eksternal seperti status, pengakuan dan perhatian.Kelima, aktualisasi diri, yaitu dorongan untuk menjadi apa yang ia mampu menjadi, mencakup: kebutuhan menjadi kreatif dan untuk dapat merealisasikan potensinya secara penuh.

Terdapat beberapa teori motivasi, seperti teori dua faktor dikemukakan oleh Herzberg yang menyebutkan adanya dua 
faktor yang menentukan motivasi seseorang yaitu faktor motivator dan kesehatan (hygiene). Teori ERG yang dikembangkan Alderfer yang mengelompokkan kebutuhan manusia yang dapat dijadikan motivasi adalah ebutuhan eksistensi, kebutuhan hubungan, dan kebutuhan pertumbuhan. Teori motivasi berprestasi Mc Clelland yang memfokuskan pada tiga kebutuhan manusia yaitu Achivement (kebutuhan akan kekuasaan), Power (kebutuhan akan kekuasaan), dan Affiliation (kebutuhan untuk berafiliasi/berkelompok). Beberapa penelitian telah dilakukan dengan menggunakan teori motivasi tingkat kebutuhan Maslow. Seperti penelitian Aprilia dkk. (2017) menyimpulkan bahwa motivasi memiliki pengaruh secara signifikan positif terhadap kinerja karyawan RS Islam Ibni Sina Pekanbaru. Andriansyah (2017) dalam penelitiannya juga menyimpulkan bahwa motivasi memiliki pengaruh secara signifikan positif terhadap kinerja karyawan pada Rumah Sakit Jiwa Amino Gondohutomo Provinsi Jawa Tengah. Berdasar landasan teori dan penelitian terdahulu, maka disusun hipotesis ketiga:

H3: Motivasi secara parsial berpengaruh positif terhadap kinerja karyawan RS Ludiro Husada Tama Yogyakarta.

\section{Kinerja Karyawan}

Menurut Sedarmayanti (2016) kinerja adalah hasil kerja seorang pekerja, sebuah proses manajemen atau suatu organisasi secara keseluruhan, dimana hasil kerja tersebut harus dapat ditunjukkan buktinya secara konkrit dan dapat diukur. Mangkunegara (2013) menjelaskan bahwa kinerja merupakan hasil kerja secara kualitas dan kuantitas yang dicapai oleh seorang pegawai dalam melaksanakan tugasnya sesuai dengan tanggung jawab yang diberikan kepadanya.

Strategi manajemen kinerja merupakan proses untuk mengukur keluaran dalam bentuk kinerja yang dihasilkan, dibandingkan dengan harapan yang diekspresikan sebagai sasaran. Sedarmayanti (2016) mengatakan strategi manajemen kinerja antara lain pertama, perbaikan kinerja dalam mencapai keefektifan organisasi dan individu agar hal yang tepat dapat dilaksanakan dengan berhasil.Kedua, strategi manajemen kinerja mengenai pengembangan karyawan. perbaikan manajemen tidak dapat tercapai, kecuali terdapat proses yang efektif dari pengembangan yang berkelanjutan. Ketiga, strategi manajemen kinerja mengenai pemuasan kebutuhan dan harapan dari semua pihak terkait, seperti organisasi, pemilik, manajemen, karyawan, pelanggan, pemasok dan masyarakat.

Faktor-faktor yang mempengaruhi kinerja menurut Sedarmayanti (2016) meliputi pertasi kerja, hasil kerja pegawai dalam menjalankan tugas.Kedua, keahlian, tingkat kemampuan teknis yang dimiliki oleh pegawaidalam menjalankan tugas yang dibebankan kepadanya. Ketiga, perilaku, mencakup kejujuran, tanggung jawab dan disiplin. Keempat, kepemimpinan, merupakan aspek kemampuan manajerial dan seni dalam memberikan pengaruh kepada orang lain untuk mengkoordinasikan pekerjaan secara tepat dan cepat, termasuk pengambilan keputusan, dan penentuan prioritas.

Penelitian mengenai faktor-faktor yang diduga berpengaruh terhadap kinerja sudah banyak dilakukan. Beberapa peneliti terdahulu baik yang dilakukan di rumah sakit maupun non rumah sakit banyak yang menggunakan variabel beban kerja, stres kerja, dan motivasi. Penelitian Andriansyah (2017) menyimpulkan bahwa beban kerja, stres kerja dan motivasi secara simultan berpengaruh terhadap kinerja perawat pada Rumah Sakit Jiwa Amino Gondohutomo Provinsi Jawa Tengah. Demikian dengan penelitian Aprilia dkk. (2017) juga menyimpulkan bahwa Beban Kerja, Stres Kerja dan motivasi Kerja Terhadap Kinerja 
Perawat Rumah Sakit Islam Ibnu Sina Pekanbaru. Mengacu pada landasan teori, dan dari penelitian terdahulu, diajukan hipotesis keempatsebagai berikut:

H4: beban kerja, stres kerja,dan motivasi secara simultan berpengaruh terhadap kinerja karyawan RS Ludira Husada Tama.

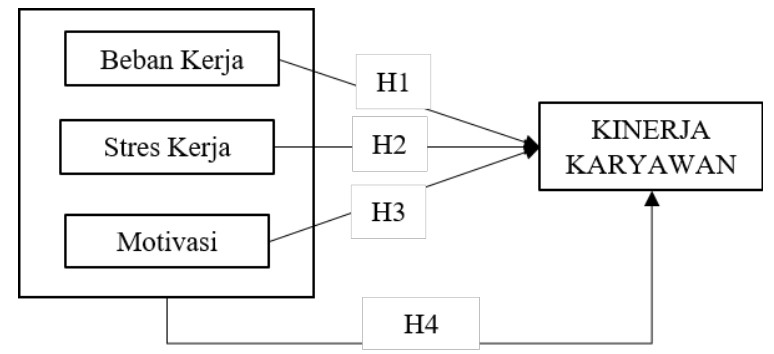

Gambar 1. Model Penelitian

\section{METODE PENELITIAN}

Populasi dalam penelitian ini adalah seluruh karyawan medis dan non medis RS Ludira Husada Tama Yogyakarta sebanyak 182 orang. Dalam penelitian ini tidak seluruh anggota populasi diambil, melainkan hanya sebagian dari populasi.Teknik pengambilan sampel pada penelitian ini adalah Probability Sampling dengan metode Proportional Stratified Random Sampling. Pengambilan anggota sampel dari populasi dilakukan secara acak. Jumlah sampel ditentukan berdasarkan metode Slovin dengan tingkat kesalahan yang ditoleransi sebesar 5\%, diperoleh sampel sebanyak 125 responden. Metode pengumpulan data dengan kuesioner, dengan menggunakanskala likert 5 tingkat persetujuan, skor 5 sangat setuju sampai dengan skor 1 sangat tidak setuju.

Data-data tersebut kemudian dianalisis dengan regresi linear berganda untuk mengetahui arah hubungan antara dua atau lebih variabel independen dengan variabel dependen serta dilakukan uji hipotesis parsial (uji t) dan uji hipotesis simultan (uji F). Asumsi-asumsi yang mendasari analisis ini adalah 1) populasi yang akan diteliti berdistibusi normal, 2) tidak ada hubungan linear antara variabel independen dalam model regresi, 3) tidak ada ketidaksamaan varian dari variabel dari residual untuk semua pengamatan pada model regresi. Oleh karena itu dilakukan uji asumsi klasik seperti normalitas, multikolinearitas, dan heterokedastisitas. Untuk melihat seberapa besar variabel-variabel bebas mampu nmenerangkan variasi variabel terikatnya digunakan Adjusted R Square.

\section{HASIL DAN PEMBAHASAN}

Dari penyebaran kuesioner kepada 125 responden, kuesiner kembali dan diisi lengkap sebanyak 110 kuesioner sehingga respon rate (tingkat pengembalian) kuesioner dalam penelitian ini adalah $88 \%$. Di rumah sakit ini pekerjaan dikelompokkan menjadi dua, divisi pekerjaan medis dan non medis. Divisi pekerjaan medis dengan persentase sebesar $59 \%$ dan non medis dengan persentase $41 \%$. Proporsi non medis yang lebih sedikit dari medis, karena di Rumah Sakit divisi non medis merupakan supporting unit untuk divisi medis.Yang termasuk divisi non medis adalah bagain keuangan, bagian sumberdaya manusia dan umum.

Dari 110 responden, jumlah responden pria sebesar $29 \%$ dan wanita $71 \%$. Proporsi ini menunjukkan kekhususan rumah sakit, dimana jumlah pegawai wanita lebih banyak dari pria. Di rumah sakit pada umumnya, khususnya di RS Ludiro Husada Tama para wanita paling banyak bekerja sebagai perawat. Mayoritas responden berpendidikan diploma dengan persentase $42 \%$. Sesuai dengan persyaratan untuk menjadi perawat dan tenaga medis lainnya adalah pendidikan Diploma. Pendidikan tertinggi S2, yaitu para dokter yang telah menyelesaikan program spesialis.Untuk pendidikan SMA sederajat sesuai dengan persyaratan yaitu pada clening service, driver, dan petugas keamanan, dan dapur. 


\section{Uji Validitas}

Uji validitas dilakukan untuk 25 item pernyataan dengan tingkat signifikansi $5 \%$ dengan uji dua sisi dan jumlah data (n) $=110$, dengan $\mathrm{df}=\mathrm{n}-2$ atau $110-2=108$ maka diperoleh rtabel sebesar 0,187. Hasil Uji Validitas isi dan jumlah data $(n)=110$, dengan df $=\mathrm{n}-2$ atau 110-2 = 108 maka diperoleh $r$ tabel sebesar 0,187 .

Semua item pertanyaan pada variabel independen dan variabel dependen memiliki nilai lebih dari 0,187. Dapat disimpulkan bahwa item pernyataan masing-masing variabel dinyatakan valid dan dapat dijadikan sebagai instrumen penelitian.

\section{Uji Reliabilitas}

Uji reliabilitas dengan Cronbach's Alpha dimaksudkan untuk menguji konsisten jawaban responden. Hasil pengujian reliabilitas untuk semua item pernyataan diperoleh nilai $>0,6$, sehingga dapat disimpulkan semua item pernyataan dalam penelitian penelitian ini telah memenuhi syarat reliabilitas.

Tabel 1. Hasil Uji Validitas

\begin{tabular}{ccccc}
\hline Variabel & Pertanyaan & Pearson Correlation & r tabel & Keterangan \\
\hline & 1 & 0,660 & 0,187 & Valid \\
Beban Kerja & 2 & 0,556 & 0,187 & Valid \\
(X1) & 3 & 0,459 & 0,187 & Valid \\
& 4 & 0,655 & 0,187 & Valid \\
& 5 & 0,553 & 0,187 & Valid \\
& 6 & 0,493 & 0,187 & Valid \\
\hline Stres Kerja & 1 & 0,712 & 0,187 & Valid \\
(X2) & 2 & 0,729 & 0,187 & Valid \\
& 3 & 0,443 & 0,187 & Valid \\
& 4 & 0,585 & 0,187 & Valid \\
& 5 & 0,740 & 0,187 & Valid \\
& 6 & 0,622 & 0,187 & Valid \\
Motivasi & 7 & 0,723 & 0,187 & Valid \\
(X3) & 1 & 0,740 & 0,187 & Valid \\
& 2 & 0,724 & 0,187 & Valid \\
& 3 & 0,518 & 0,187 & Valid \\
& 4 & 0,698 & 0,187 & Valid \\
& 5 & 0,747 & 0,187 & Valid \\
Kinerja Karyawan & 6 & 0,774 & 0,187 & Valid \\
(Y) & 1 & 0,557 & 0,187 & Valid \\
& 2 & 0,674 & 0,187 & Valid \\
& 3 & 0,649 & 0,187 & Valid \\
& 4 & 0,755 & 0,187 & Valid \\
& 5 & 0,533 & 0,187 & Valid \\
& 6 & 0,518 & 0,187 & Valid \\
\hline
\end{tabular}

Sumber: data diolah 
Tabel 2. Hasil Uji Reliabilitas

\begin{tabular}{lll}
\hline \multicolumn{1}{c}{ Variabel } & Cronbach's Alpha & Keterangan \\
\hline Beban Kerja & 0,665 & Reliabel \\
Stres Kerja & 0,777 & Reliabel \\
Motivasi & 0,795 & Reliabel \\
Kinerja & 0,677 & Reliabel \\
\hline
\end{tabular}

\section{Uji Normalitas}

Uji normalitas akan digunakan uji one sample kolmogrof-smirnov dengan menggunakan taraf signifikansi 0,05. Data dinyatakan berdistribusi normal jika signifikansi lebih besar dari 0,05.

Tabel 3. Hasil Uji Normalitas One-Sample Kolmogorov-Smirnov Test

\begin{tabular}{lll}
\hline & & $\begin{array}{l}\text { Unstandardized } \\
\text { Residual }\end{array}$ \\
\hline $\mathrm{N}$ & & 110 \\
Normal Parameters ${ }^{\mathrm{a}, \mathrm{b}}$ & Mean & OE-7 \\
Std. Deviation & & 2.24482201 \\
Most Extreme Differences & Absolute & .042 \\
& Positive & .036 \\
& Negative & .042 \\
Kolmogorov-Smirnov Z & & .437 \\
Asymp. Sig. (2-tailed) & & .991 \\
\hline
\end{tabular}

a. Test distribution is Normal.

b. Calculated from data.

Nilai signifikansi dari pengujian one sample kolmogrof-smirnov sebesar 0,437 dan Asymp.sig sebesar 0,991. Nilai ini menunjukkan bahwa hasil pengujian lebih besar dari 0,05, sehingga dapat disimpulkan nilai residual distribusi secara normal.

\section{Uji Multikolinearitas}

Persyaratan yang harus terpenuhi dalam model regresi adalah tidak adanya multikolinearitas. Model pengujian yang digunakan yaitu dengan melihat nilai variance inflation factor (VIF). Menurut Santoso (dalam Wiyono, 2011), jika VIF lebih besar dari 5, maka variabel tersebut mempunyai persoalan dengan variabel bebas lainnya.

Tabel 4. Hasil Uji Multikolinearitas

\begin{tabular}{lcc}
\hline \multirow{2}{*}{\multicolumn{1}{c}{ Model }} & \multicolumn{2}{c}{ Collinearity Statictics } \\
\cline { 2 - 3 } & Tolerance & VIF \\
\hline 1(Constant) & & \\
Ln beban_kerja & .914 & 1.094 \\
Ln stres_kerja & .899 & 1.112 \\
Ln motivasi & .960 & 1.042 \\
\hline
\end{tabular}

Nilai variance inflation factor (VIF) ketiga variabel beban kerja $(\mathrm{X} 1)=1,094$, Stres Kerja $(\mathrm{X} 2)=1,112$, dan motivasi $(\mathrm{X} 3)=$ 1,042. Ketiga variabel tersebut memiliki VIF lebih kecil dari 5, sehingga dapat disimpulkan bahwa antara variabel independen tidak terjadi masalah multikolinearitas.

\section{Uji Heterokedastisitas}

Uji heterokedastisitas digunakan untuk mengetahui ada atau tidaknya penyimpangan asumsi klasik heterokedastisitas, yaitu adanya ketidaksamaan varian dari residual untuk semua pengamatan pada model regresi. Adapun kriteria pengujian sebagai berikut:

Jika - ttabel $\leq$ thitung $\leq$ ttabel : tidak terdapat heterokedastisitas

Jika thitung $>$ ttabel atau -thitung $<$-ttabel: terdapat heterokedastisitas

Tabel 5. Hasil Uji Heterokedastisitas

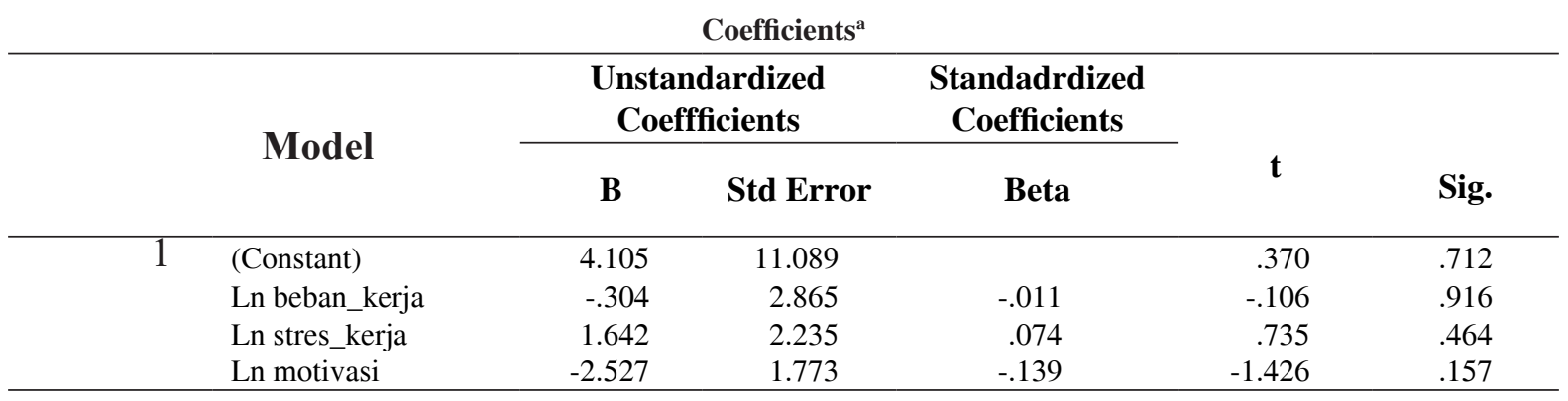

a. Dependent Variable: Kinerja_karyawan 
Nilai thitung variabel beban kerja sebesar -0,106, variabel stres kerja sebesar 0,735 , dan variabel motivasi sebesar -1,426. Sedangkan ttabel dengan $\mathrm{df}=\mathrm{n}-2$ atau 110 $2=108$, adalah 1,6591 dengan ketentuan ttabel $\leq$ thitung $\leq$ ttabel, maka didapakan hasil untuk variabel beban kerja -1,6591 $\leq-0,106 \leq 1,6591$, untuk variabel stres kerja $-1,6591 \leq 0,735 \leq 1,6591$, dan untuk variabel motivasi $-1,6591 \leq-1,426 \leq$
1,6591 disimpulkan tidak ditemukan masalah heterokedastisitas pada model regresi.

\section{Regresi Linear Berganda}

Dalam penelitian ini analisis regresi linier berganda untuk menguji arah hubungan antara variabel independen (beban kerja, stres kerja, dan motivasi) terhadap variabel dependen (kinerja karyawan).

Tabel 6. Hasil Uji Regresi Berganda

Coefficients $^{\mathrm{a}}$

\begin{tabular}{lcccccc}
\hline \multirow{2}{*}{ Model } & \multicolumn{2}{c}{$\begin{array}{c}\text { Unstandardized } \\
\text { Coefficients }\end{array}$} & $\begin{array}{c}\text { Standardized } \\
\text { Coefficients }\end{array}$ & T & Sig. \\
\cline { 2 - 4 } & B & Std. Error & Beta & & \\
\hline (Constant) & .471 & 3.803 & & .124 & .902 \\
beban_kerja & .565 & .121 & .400 & 4.650 & .000 \\
stres_kerja & .142 & .086 & .143 & 1.644 & .103 \\
Motivasi & .198 & .083 & .200 & 2.389 & .019 \\
\hline
\end{tabular}

a. Dependent Variable: Kinerja_karyawan

$\mathrm{Y}=\boldsymbol{\alpha}+\beta 1 \mathrm{X} 1+\beta 1 \mathrm{X} 2+\beta 1 \mathrm{X} 3$

$\mathrm{Y}=0,471+0,565 \mathrm{X} 1+0,142 \mathrm{X} 2+0,198 \mathrm{X} 3$

a. Koefisien regresi beban kerja $(\mathrm{X} 1)=$ 0,565 , koefisien bernilai positif artinya variabel beban kerja mempunyai arah hubungan yang positif dengan kinerja karyawan.

b. Koefisien regresi stres kerja $(\mathrm{X} 2)=$ 0,142 , koefisien bernilai positif artinya variabel stres kerja mempunyai arah hubungan yang positif dengan kinerja karyawan.

c. Koefisien regresi motivasi $(\mathrm{X} 3)=0,198$, koefisien bernilai positif artinya variabel motivasi mempunyai arah hubungan yang positif dengan kinerja karyawan.

d. Dari ketiga variabel independen, yang paling besar peangaruhnya terhadap kinerja karyawan adalah variabel beban kerja, yang ditunjukkan dengan besaran koefisien regresi 0,565.

\section{Uji t}

Uji $\mathrm{t}$ digunakan untuk mengetahui seberapa jauh pengaruh masing-masing (secara parsial) koefisien regresi variabel independen $(\mathrm{X})$ yang terdiri dari beban kerja, stres kerja, dan motivasi terhadap variabel dependen (Y) yaitu kinerja karyawan. 
Tabel 7. Hasil Uji t

Coefficients $^{\mathrm{a}}$

\begin{tabular}{lcccccc}
\hline \multirow{2}{*}{ Model } & \multicolumn{2}{c}{$\begin{array}{c}\text { Unstandardized } \\
\text { Coefficients }\end{array}$} & $\begin{array}{c}\text { Standardized } \\
\text { Coefficients }\end{array}$ & T & Sig. \\
\cline { 2 - 4 } & B & Std. Error & Beta & & \\
\hline (Constant) & .471 & 3.803 & & .124 & .902 \\
beban_kerja & .565 & .121 & .400 & & 4.650 & .000 \\
stres_kerja & .142 & .086 & .143 & & 1.644 & .103 \\
Motivasi & .198 & .083 & .200 & & 2.389 & .019 \\
\hline
\end{tabular}

a. Dependent Variable: Kinerja_karyawan

Dari hasil perhitungan uji $t$ dapat disimpulkan sebagai berikut:

a. Variabel beban kerja (X1) memiliki tingkat signifikansi sebesar $0,000<$ 0,05. Nilai tersebut membuktikan H1 diterima, yang berarti bahwa variabel beban kerja secara parsial berpengaruh terhadap kinerja karyawan.

b. Variabel stres kerja (X2) memiliki tingkat signifikansi sebesar $0,103>$ 0,05 . Nilai tersebut membuktikan $\mathrm{H} 2$ ditolak, yang berarti bahwa variabel stres kerja secara parsial tidak berpengaruh terhadap kinerja karyawan. c. Variabel motivasi (X3) memiliki tingkat signifikansi sebesar $0,019<0,05$. Nilai tersebut membuktikan H3 diterima, yang berarti bahwa variabel motivasi secara parsial berpengaruh terhadap kinerja karyawan.

\section{Uji F}

Uji $F$ atau uji serentak yaitu uji untuk melihat bagaimana pengaruh seluruh variabel independen secara simultan atau bersamasama terhadap variabel dependen.Wiyono (2011).Dalam penelitian ini dengan $\square=0,05$ pada tingkat kepercayaan $95 \%$.

Tabel 8. Hasil Uji F

\begin{tabular}{lccccc}
\multicolumn{7}{c}{ ANOVA $^{\mathrm{b}}$} \\
\hline \multicolumn{1}{c}{ Model } & Sum of Squares & Df & Mean Square & F & Sig. \\
\hline 1 Regression & 217.815 & 3 & 72.605 & 14.011 & $.000^{\mathrm{b}}$ \\
Residual & 549.276 & 106 & 5.182 & & \\
Total & 767.091 & 109 & & \\
\hline dependent variable: kinerja_karyawan & & \\
Predictors: (Constant), beban_kerja, stress_kerja, motivasi
\end{tabular}


Hasil uji F diperoleh $\mathrm{F}$ hitung sebesar 14,011 dan probabilitas sebesar 0,000. Karena sig Fhitung $<0,05$ maka $\mathrm{H} 4$ diterima atau dapat disimpulkan bahwa secara simultan ada pengaruh antara variabel beban kerja, stres kerja, dan motivasi terhadap kinerja karyawan.

\section{Koefisien Determinasi}

Menurut Ghozali (2009), koefisien determinasi digunakan untuk mengukur prosentase total variasi variabel dependen $(\mathrm{Y})$ yang dijelaskan oleh variabel independen (X) di dalam model regresi. Regresi dengan lebih dari dua variabel bebas digunakan Adjusted $R^{2}$ sebagai koefisien determinasi.

Tabel 9. Koefisien Determinasi

\begin{tabular}{rcrrr}
\hline Model & R & $\begin{array}{c}\text { R } \\
\text { Square }\end{array}$ & $\begin{array}{r}\text { Adjusted } \\
\text { R Square }\end{array}$ & $\begin{array}{r}\text { Std error of } \\
\text { the estimate }\end{array}$ \\
\hline 1 & $.533^{\mathrm{a}}$ & .284 & .264 & 2.27637 \\
\hline
\end{tabular}

Predictor: (constant), beban_kerja, stress_kerja, motivasi

Nilai Adjusted $R^{2}$ sebesar 0,264 yang menunjukkan bahwa 26,4\% kinerja karyawan dapat dijelaskan oleh variabel beban kerja, stres kerja, motivasi, dan sisanya sebesar $73,6 \%$ dijelaskan oleh variabel lain yang tidak dimasukkan dalam penelitian ini.

\section{KESIMPULAN DAN SARAN}

Berdasarkan hasil penelitian mengenai pengaruh beban kerja, stres kerja, dan motivasi terhadap kinerja karyawan RS Ludira Husada Tama, maka dapat diambil kesimpulan sebagai berikut:

1. Variabel beban kerja dan motivasi secara parsial berpengaruh terhadap kinerja aryawan RS Ludira Husada Tama Yogyakarta. Sedangkan untuk variabel stres kerja secara parsial tidak berpengaruh terhadap kinerja karyawan RS Ludira Husada Tama Yogyakarta.

2. Variabel beban kerja, stres kerja, dan motivasi secara simultan berpengaruh terhadap kinerja karyawan RS Ludira
Husada Tama Yogyakarta.

3. Dari ketiga variabel, yang paling besar pengaruhnya terhadap kinerja karyawan adalah variabel beban kerja.

4. Variabel beban kerja, stres kerja, dan motivasi memberikan sumbangan pengaruh sebesar $26,4 \%$ sisanya sebesar $73,6 \%$ dipengaruhi oleh variabel lain yang tidak dimasukkan dalam model penelitian.

Beberapa saran yang diajukan:

1. Bagi peneliti selanjutnya, oleh karena $\mathrm{R}$ Square kecil, maka perlu menambahkan atau mengganti variabel-variabel lain yang diperkirakan dapat mempengaruhi kinerja karyawan.

2. Bagi RS Ludira Husada Tama, untuk lebih memperhatikan pembagian volume dan waktu kerja yang diberikan kepada setiap karyawannya, agar sesuai dengan kemampuan tubuh karyawan. Mengingat beban kerja ini mempunyai pengaruh yang paling besar terhadap kinerja karyawan.

\section{REFERENSI}

Andriansyah, Fahreza Ilham. 2017. Pengaruh Beban Kerja, Stress Kerja dan Motivasi terhadap Kinerja Perawat pada Rumah Sakit Jiwa Amino Gondohutomo Provinsi Jawa Tengah. Skripsi. Universitas Diponegoro Semarang.

Aprilia, Friska, Samsir Samsir, dan Arwinence Pramadewi . 2017. Pengaruh Beban Kerja, Stres Kerja, dan Motivasi Kerja terhadap Kinerja Perawat Rumah Sakit Islam Ibnu Sina Pekanbaru. Jurnal Mahasiswa . Fakultas Ekonomi Universitas Riau.

Darmawan, Dimas Yusuf. 2017. Pengaruh Keselamatan dan Kesehatan Kerja (K3), Pelatihan, dan Motivasi terhadap Kinerja pada Tim Reaksi 
Cepat (TRC) BPBD DIY. Skripsi. Sekolah Tinggi Ilmu Manajemen YKPNYoyakarta.

Ghozali, Imam. 2009. Aplikasi Analisis Multivariate dengan Program IBM SPSS 19. Semarang: Universitas Diponegoro.

Hanafi, Mamduh Muhammad. 2011. Manajemen. Yogyakarta: UPP STIM YKPN.

Hasibuan, Malayu S.P. 2016. Manajemen Sumber Daya Manusia. Edisi Revisi, Jakarta: PT Bumi Aksara.

Kepmenpan. 2004. Pedoman Perhitungan Kebutuhan Pegawai Berdasarkan Beban Kerja dalam Rangka Penyusunan Formasi Pegawai Negeri Sipil, https://www.menpan.go.id/ jdih/permen-kepmen/kepmenpanrb?start=30, diakses 16 November 2016.

Latifah Umi dan Sri Haryani. 2014. Pengaruh Motivasi, Pengawasan, dan Budaya Kerja terhadap Produktivitas Kerja Karyawan Perusahaan Pengecoran Alumunium SP Yogyakarta. Telaah Bisnis. Volume 15, Nomor 2.

Losyk, Bob 2007. Kendalikan Stress Anda: Cara Mengatasi Stress Dan Sukses di Tempat Kerja. Jakarta: Gramedia Pustaka Utama.

Mangkunegara, A. P. 2013. Manajemen Sumber Daya Manusia Perusahaan, Bandung: PT Remaja Rosdakarya.

Munandar, A. S. 2014. Psikologi Industri dan Organisasi, Jakarta: UI PRESS.
Pedoman Umum Penyusunan Kebutuhan Pegawai Negri Sipil, https://www. bkn.go.id, diakses 15 November 2016.

Pemendagri, 2008, Pedoman Analisis Beban Kerja di Lingkungan Departemen Dalam Negeri dan Pemerintah Daerah, https://www.kemendagri. go.id, diakses 15 November 2016.

Pusat Pengembangan Manajemen. 1994. Kamus Istilah Manajemen, Jakarta: Pustaka Binaman Pressindo.

Safaria, Triantoro dan Nofrans Eka Saputra. 2009. Manajemen Emosi Sebuah Panduan Cerdas Bagaimana Mengelola Emosi Positif dalam Hidup Anda. Jakarta: PT Bumi Aksara.

Sedarmayanti. 2016. Manajemen Sumberdaya Manusia: Reformasi Birokrasi dan Manajemen Pegawai Negeri Sipil. Bandung: PT Refika Aditama.

Tarwaka, Bakhri H.A S, Sudiajeng L. 2004. Ergonomi untuk Keselamatan, Kesehatan Kerja dan Produktivitas. Surakarta: Uniba Press.

Triatna, Cepi. 2015. Perilaku Organisasi dalam Pendidikan, Bandung: PT Remaja Rosdakarya.

Wijono, Sutarto. 2012. Psikologi Industri dan Organisasi, Jakarta: Kencana Prenada Media Group.

Wiyono, Gendro. 2011. Merancang Penelitian Bisnis dengan Alat Analisis SPSS 17.0 \& SmartPLS 2.0. Yogyakarta: UPP STIM YKPN. 
